\title{
Short communication: Change of naturally occurring benzoic acid during skim milk fermentation by commercial cheese starters
}

\author{
Noori Han, ${ }^{*}$ Sun-Young Park, ${ }^{*}$ Sun-Young Kim, ${ }^{*}$ Mi-Young Yoo, ${ }^{*}$ Hyun-Dong Paik, $†$ and Sang-Dong Lim ${ }^{* 1}$ \\ *Korea Food Research Institute, Seongnam 463-746, Korea, 13539 \\ †Division of Animal Life Science, Konkuk University, Seoul, Korea, 05029
}

\begin{abstract}
This study sought to investigate the change of naturally occurring benzoic acid (BA) during skim milk fermentation by 4 kinds of commercial cheese starters used in domestic cheese. The culture was incubated at 3 -h intervals for $24 \mathrm{~h}$ at 30,35 , and $40^{\circ} \mathrm{C}$. The BA content during fermentation by Streptococcus thermophilus STB-01 was detected after $12 \mathrm{~h}$ at all temperatures, sharply increasing at $30^{\circ} \mathrm{C}$. In Lactobacillus paracasei LC431, BA was detected after $9 \mathrm{~h}$ at all temperatures, sharply increasing until $18 \mathrm{~h}$ and decreasing after 18 $\mathrm{h}$ at 30 and $35^{\circ} \mathrm{C}$. In the case of R707 (consisting of Lactococcus lactis ssp. lactis and Lactococcus lactis ssp. cremoris), BA increased from $6 \mathrm{~h}$ to $15 \mathrm{~h}$ and decreased after $15 \mathrm{~h}$ at $40^{\circ} \mathrm{C}$. The BA during STB-01 and CHN-11 (1:1; mixture of $S$. thermophilus, Lc. lactis ssp. lactis, Lc. lactis ssp. cremoris, Lc. lactis ssp. diacetylactis, Leuconostoc mesenteroides ssp. cremoris) fermentation was detected after $3 \mathrm{~h}$ at 35 and $40^{\circ} \mathrm{C}$, sharply increasing up to $12 \mathrm{~h}$ and decreasing after $15 \mathrm{~h}$ at $35^{\circ} \mathrm{C}$, and after $6 \mathrm{~h}$, increasing up to $9 \mathrm{~h}$ at $30^{\circ} \mathrm{C}$. After $3 \mathrm{~h}$, it steadily decreased at $40^{\circ} \mathrm{C}$. The highest amount of $\mathrm{BA}$ was found during the fermentation by $\mathrm{R} 707$ at $30^{\circ} \mathrm{C} ; 15$ $\mathrm{h}$ with $12.46 \mathrm{mg} / \mathrm{kg}$.
\end{abstract}

Key words: benzoic acid, skim milk, fermentation, cheese starter

\section{Short Communication}

Natural preservatives are produced via the metabolic process of plants and animals as food materials or food processing such as fermentation. Benzoic acid, sorbic acid, and propionic acid, the compounds of food preservatives, are made of natural ingredients and are naturally produced during fermentation. In the case of

Received January 13, 2016.

Accepted July 15, 2016.

${ }^{1}$ Corresponding author: limsd@kfri.re.kr preservatives such as benzoic acid, controversy over the food standard steadily increased because there was no exact distinction between added synthetic preservative and natural preservative (Meyer et al., 2002). In addition, judging whether synthetic additions are present in the final product will often be difficult because a preservative such as benzoic acid can be naturally present regardless of raw material characteristics and manufacturing technology (Iammarino et al., 2011).

Benzoic acid is a naturally occurring metabolic product with a free or combined form and found in several plants and animals (Hegnauer, 1992). Benzoic acid is not permitted as an additive in milk but is found in cheese, fermented cream, yogurt, and other dairy products (Urbienè and Leskauskaitè, 2006; Horníčková et al., 2014). It has been reported that benzoic acid content in fermented milk and cheeses was detected up to 50 $\mathrm{mg} / \mathrm{kg}$ (Sieber et al., 1995). Rukkwamsuk et al. (2012) reported that average concentrations of benzoic acid in composite milk gradually increased from $0.09 \mathrm{ppm}$ at $0 \mathrm{~h}$ to $0.13 \mathrm{ppm}$ at $6 \mathrm{~h}$ after collection. Also, Toppino et al. (1990) reported that up to $60 \mathrm{mg} / \mathrm{kg}$ benzoic acid was detected in Provolone cheese samples. It is affected by the microorganisms used in the production of dairy products (Kisza et al., 1984; Sajko et al., 1984; Hejtmánková et al., 2000). Lactococcus lactis, Lactobacillus casei, Lactobacillus helveticus, and Streptococcus thermophilus can synthesize benzoic acid in milk (Sajko et al., 1984; García et al., 2003; Garmiene et al., 2010; Yildiz et al., 2012). According to Urbienè and Leskauskaite (2006), the benzoic acid produced during the fermentation of milk by 3 different commercial dairy starters (La-5, ABT-2, and YC-180) was approximately 14 to $23 \mathrm{mg} / \mathrm{kg}$. During the fermentation of milk with La-5, the benzoic acid content was about 5 times higher than that at the beginning of the fermentation process. The highest concentration of benzoic acid was detected in the sample fermented by La- 5 .

Mroueh et al. (2008) reported that the benzoic acid content of yogurt using commercial starters MYE95, MY900, CH1, and LYOFASTY 4.80F was reportedly 4.7 , not detected, 14.7 , and $8.5 \mathrm{mg} / \mathrm{kg}$, respectively. 
Table 1. Precision and accuracy data for the detection of benzoic acid

\begin{tabular}{|c|c|c|c|c|c|}
\hline Compound & $\begin{array}{l}\text { Spiked concentration } \\
(\mu \mathrm{g} / \mathrm{mL})\end{array}$ & $\begin{array}{l}\text { Detected concentration }^{1} \\
(\mu \mathrm{g} / \mathrm{mL})\end{array}$ & $\begin{array}{l}\text { Recovery }^{1} \\
(\%)\end{array}$ & $\begin{array}{c}\text { Intra-day } \\
(\mathrm{n}=3, \mathrm{CV} \%)^{2}\end{array}$ & $\begin{array}{c}\text { Inter-day } \\
(\mathrm{n}=9, \mathrm{CV} \%)\end{array}$ \\
\hline Benzoic acid & $\begin{array}{l}4.00 \\
2.00 \\
1.00\end{array}$ & $\begin{array}{l}3.81 \pm 0.04 \\
1.97 \pm 0.02 \\
1.00 \pm 0.02\end{array}$ & $\begin{array}{l}95.35 \pm 0.89 \\
98.60 \pm 0.80 \\
99.83 \pm 1.78\end{array}$ & $\begin{array}{l}2.09 \\
1.82 \\
4.02\end{array}$ & $\begin{array}{l}3.19 \\
1.97 \\
2.66\end{array}$ \\
\hline
\end{tabular}

${ }^{1}$ Values are shown as the mean \pm SEM.

${ }^{2} \mathrm{CV} \%$ indicates the coefficient of variation in percentage.

After $25 \mathrm{~d}$ of storage, the development of benzoic acid of yogurt samples steadily increased. The benzoic acid content differed according to the kind of starters and fermentation during storage time.

Thus, this study aimed to investigate the change of naturally produced benzoic acid during skim milk fermentation by 4 kinds of commercial cheese starters [STB-01, LC431, R707, and STB-01+CHN11 (1:1)] at different temperature.

Four kinds of cheese starters were used: STB-01 composed of Streptococcus thermophilus; LC431 composed of Lactobacillus paracasei; R707 composed of Lactococcus lactis ssp. lactis and Lactococcus lactis ssp. cremoris; and STB01+CHN11 (1:1) composed of Streptococcus thermophilus, Lactococcus lactis ssp. lactis, Lactococcus lactis ssp. cremoris, Lactococcus lactis ssp. diacetylactis, and Leuconostoc mesenteroides ssp. cremoris. The cheese starters were usually used for making cheese such as Camembert cheese, Brie cheese, string cheese, fresh cheese, and mozzarella cheese in industry. These cheese starters were obtained from Christian Hansen Lab (Hørsholm, Denmark).

The number of viable starter strains was determined by serial 10 -fold dilution in $0.1 \%$ peptone water. About $10^{5} \mathrm{cfu} / \mathrm{mL}$ of starter strain was inoculated into $10 \%$ reconstituted skim milk; the culture was then incubated at 3-h intervals for $18 \mathrm{~h}$ at 30,35 , and $40^{\circ} \mathrm{C}$. All 4 plates were incubated aerobically at $37^{\circ} \mathrm{C}$ for $48 \mathrm{~h}$ using a BCP plate count agar (Eiken, Tokyo, Japan). The pH was measured using a pH meter (Inolab $7110 \mathrm{pH}$ BNC, WTW, Weilheim, Germany).

For analysis of benzoic acid production, sample preparation was conducted in accordance with the Korean Food Additives Codex (MFDS, 2014). A 5-g sample was dissolved in $50 \mathrm{~mL}$ of distilled water, and $5 \mathrm{~mL}$ of this solution was mixed with $0.5 \mathrm{~mL}$ of $0.1 \mathrm{~N} \mathrm{HCl}$ and 0.5 $\mathrm{mL}$ of $0.005 M$ cetyltrimethyl ammonium chloride solution (sample solution). A Sep-Pak C18 cartridge (Waters, Milford, MA) was preconditioned for benzoic acid by consecutively passing $10 \mathrm{~mL}$ of methanol and $10 \mathrm{~mL}$ of $0.005 M$ cetyltrimethyl ammonium chloride solution. The sample solutions passed through the Sep-Pak C18 cartridge at a flow rate of $2 \mathrm{~mL} / \mathrm{min}$. Afterward the SepPak C18 cartridge was washed with $10 \mathrm{~mL}$ of distilled water and eluted with $10 \mathrm{~mL}$ of methanol to fill with $100 \%$ methanol. The entire solution was filtered with a $0.45-\mu \mathrm{m}$ filter before being injected into the HPLC system. Commercial standards of benzoic acid with $99 \%$ purity were purchased from Sigma (Saint Louis, MO). The HPLC-grade solvents were purchased from J. T. Baker (Center Valley, PA). Other reagents (analytical grade) were purchased from Wako (Tokyo, Japan). An analysis of benzoic acid was performed using HPLC with a photodiode array detector (PDA; Shiseido Co. Ltd., Tokyo, Japan). The operating conditions were as follows: column temperature of $35^{\circ} \mathrm{C}$, flow rate of 1.0 $\mathrm{mL} / \mathrm{min}$, injection volume of $10 \mu \mathrm{L}$, and PDA detection at $217 \mathrm{~nm}$. The maximum extinction wavelength of benzoic acid was $230 \mathrm{~nm}$. Chromatographic separations were performed on SP Column MF C8 (5.0 $\mu \mathrm{m}$ particle size: $150 \times 4.6 \mathrm{~mm}$ i.d.; Shiseido Co. Ltd.), with the mobile phase consisting of $0.1 \%$ tetrabutylammonium hydroxide (Phase A) and 100\% acetonitrile (Phase B). The following gradient was applied: 0 to $2.5 \mathrm{~min}, 25 \%$ B; 2.5 to $7.0 \mathrm{~min}, 25$ to $35 \% \mathrm{~B}$; 7.0 to $12.0 \mathrm{~min}, 35$ to $40 \% \mathrm{~B}$; and 12.0 to $15.0 \mathrm{~min}, 40$ to $30 \% \mathrm{~B}$. Linearity test was performed by 3 series of analysis on 3 different days by injecting 2 mixture standard solutions at 1.00 , 2.00, and $4.00 \mu \mathrm{g} / \mathrm{mL}$. Limits of detection (LOD) and quantification (LOQ) were calculated according to the following equations: $\mathrm{LOD}=3.3 \times \mathrm{s} / \mathrm{S}$ and $\mathrm{LOQ}=10$ $\times \mathrm{s} / \mathrm{S}$, where $\mathrm{s}$ is the standard deviation of $\mathrm{y}$ intercepts of regression analysis and $\mathrm{S}$ is the slope of a calibration curve. Recovery was calculated using a standard addition method.

Statistical analysis was performed with the Statistical Package for Social Sciences (SPSS Inc., Chicago, IL). The differences were analyzed using one-way ANOVA with Duncan's multiple range tests. Values of $P<0.05$ and $P<0.01$ were considered statistically significant. All data are expressed as the mean \pm standard error of the mean.

To evaluate the HPLC-PDA method, linearity, limits of detection, limits of quantification, recovery, and reproducibility were calculated. The LOD is defined as the smallest peak detected with signal height that is 3 times that of the baseline; LOQ refers to the lowest level of analysis that can be determined with an accept- 


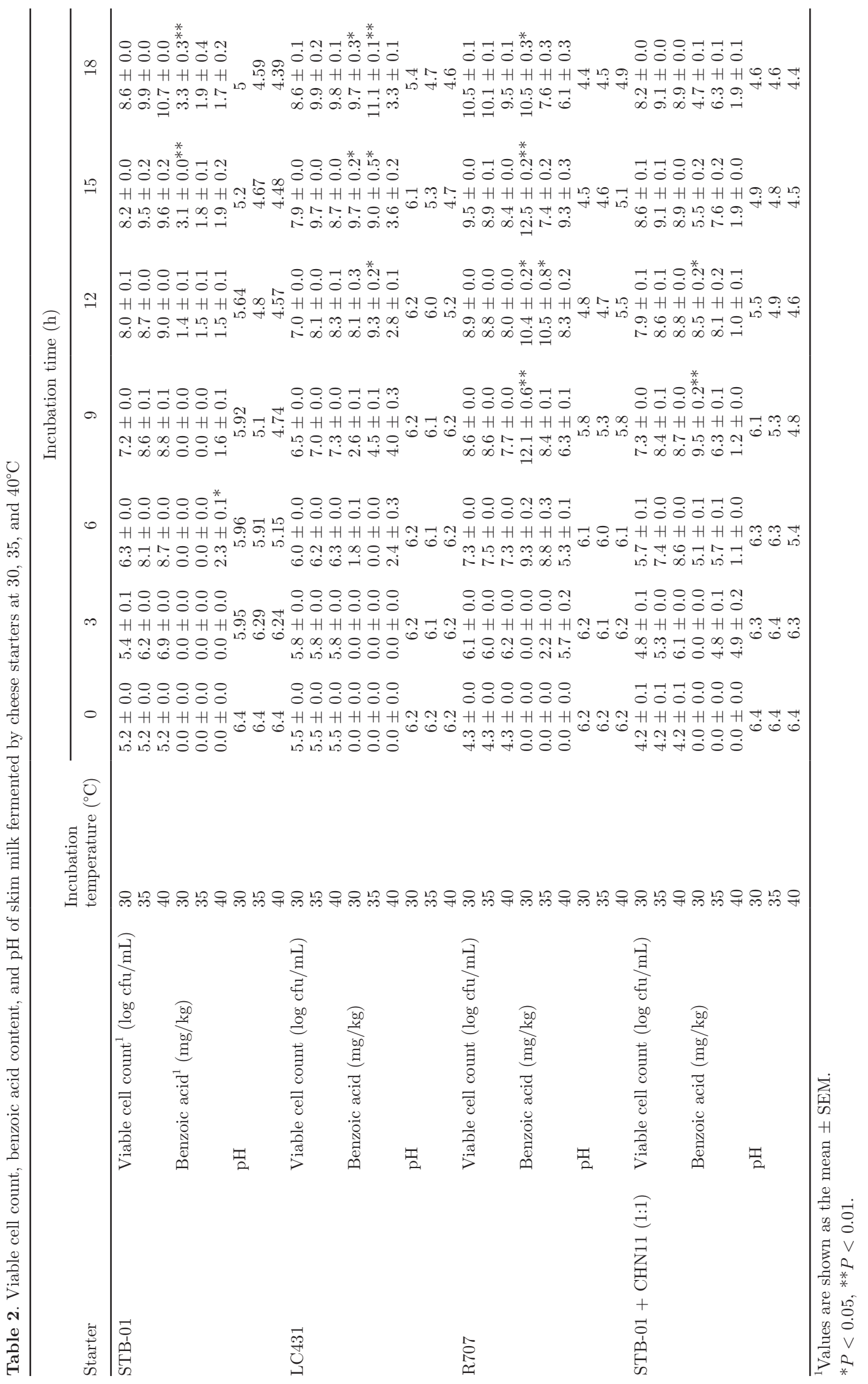


able degree of confidence. At the same time, recovery was determined by 3 sets of samples with benzoic acid at concentrations of 1.0, 2.0, and $4.0 \mu \mathrm{g} / \mathrm{mL}$. Recoveries were obtained at levels $1.00,1.97$, and $3.81 \mu \mathrm{g} /$ $\mathrm{mL}$ in samples, varying from $99.83,98.60$, and $95.35 \%$, respectively (Table 1 ). The linearity range was 0.20 to $8.00 \mu \mathrm{g} / \mathrm{mL}$. In the regression equation $\mathrm{y}=\mathrm{ax}+\mathrm{b}$, where $\mathrm{y}$ is the peak area, $\mathrm{x}$ refers to the concentration of compounds $(\mu \mathrm{g} / \mathrm{mL})$, a is the slope, and b is the intercept, the slope, intercept, and correlation coefficient were calculated to be $8.63 \times 10^{3},-2.34 \times 10^{3}$, and 1.00 , respectively. The LOD and LOQ values were calculated to be 0.08 and $0.23 \mu \mathrm{g} / \mathrm{mL}$, respectively.

The changes in viable cell count, benzoic acid content, and $\mathrm{pH}$ during the fermentation of skim milk with 4 kinds of cheese starters were in Table 2. The optimum growth temperature of $S$. thermophilus STB-01 culture was $40^{\circ} \mathrm{C}$. The $\mathrm{pH}$ continuously decreased in accordance with the fermentation time. In particular, $\mathrm{pH}$ steadily decreased during fermentation time at $40^{\circ} \mathrm{C}$ from $\mathrm{pH} 6.4$ to $\mathrm{pH}$ 4.4. In terms of benzoic acid content, the highest value was recorded after $15 \mathrm{~h}$ incubation from $30^{\circ} \mathrm{C}$ with $3.3 \mathrm{mg} / \mathrm{kg}$. Lactic acid bacteria could convert hippuric acid of phenylalanine, which is naturally present in milk, into benzoic acid (Nishimoto et al., 1969; Sieber et al., 1995; Hejtmánková et al., 2000; Tavaria et al., 2002). Oxidation of benzaldehyde may also contribute to benzoic acid production (Sieber et al., 1995). Another possible mechanism for the production of benzoic acid could be the anaerobic metabolism of phenol (Ping et al., 2009). It could be considered a natural component of milk and milk products.

The number of viable Lactobacillus paracasei LC431 cells was sharply increased at 35 and $40^{\circ} \mathrm{C}$. The optimum growth temperature of L. paracasei LC431 was $35^{\circ} \mathrm{C}$. During fermentation time, the growth of LC431 reached $10.2 \log \mathrm{cfu} / \mathrm{mL}$. Moreover, the production of benzoic acid constantly increased at $35^{\circ} \mathrm{C}$ from 12 to $18 \mathrm{~h}$ up to $11.13 \mathrm{mg} / \mathrm{kg}$. The changes in $\mathrm{pH}$ showed a similar pattern with changes in benzoic acid production. The $\mathrm{pH}$ values rapidly decreased after $9 \mathrm{~h}$ up to $\mathrm{pH} 4.23$ at $40^{\circ} \mathrm{C}$. In case of R707 culture, the optimum growth temperature was $30^{\circ} \mathrm{C}$, and the growth of R707 was up to $10.5 \log \mathrm{cfu} / \mathrm{mL}$ at the end of fermentation. Skim milk inoculated with R707 contained up to 12.5 $\mathrm{mg} / \mathrm{kg}$ of benzoic acid after $15 \mathrm{~h}$ fermentation at $30^{\circ} \mathrm{C}$. Such was the highest production of benzoic acid among other commercial starters including STB-01, LC431, and STB01+CHN11. The benzoic acid content decreased after $18 \mathrm{~h}$. Benzoic acid considered to have decompounded through denitrifying (Ziegler et al., 1987). Braun and Gibson (1984) investigated the aerobic and anaerobic growth on the benzoate of a denitrifying Pseudomonas sp. strain, KB740. Evans (1977) found that bacteria can degrade benzoic acid in the absence of molecular $\mathrm{O}_{2}$ through nitrate respiration.

The mixed STB-01 and CHN11 culture tended to lead the strain's growth by Streptococcus thermophilus. At $40^{\circ} \mathrm{C}$, during the next $6 \mathrm{~h}$, the mixed STB-01 and CHN11 strain cultures and $\mathrm{pH}$ changed markedly. In the case of 30 and $35^{\circ} \mathrm{C}$, the strain cultures steadily grew up to about $9 \log \mathrm{cfu} / \mathrm{mL}$ for $15 \mathrm{~h}$. During $6 \mathrm{~h}$ fermentation, the strain cultures showed a lag phase, with the $\mathrm{pH}$ reaching 5.5. The amounts of benzoic acid were detected after $3 \mathrm{~h}$ at 35 and $40^{\circ} \mathrm{C}$ sharply increasing up to $12 \mathrm{~h}$ and decreasing after $15 \mathrm{~h}$ at $35^{\circ} \mathrm{C}$ and after $6 \mathrm{~h}$, increasing up to $9 \mathrm{~h}$ at $30^{\circ} \mathrm{C}$. Benzoic acid is considered to decrease with the lactic acid bacteria reaching the death phase after a stationary phase during lactic acid bacteria's metabolic process (Yildiz et al., 2012). The benzoic acid was naturally produced and the content of benzoic acid was different depending on the incubation time, temperature, and the kinds of starters. The range of benzoic acid content was $0.0 \sim 12.5 \mathrm{mg} /$ $\mathrm{kg}$, and the highest concentration of benzoic acid was detected in the skim milk fermented by R707 composed of Lactococcus lactis ssp. lactis and Lactococcus lactis ssp. cremoris.

\section{ACKNOWLEDGMENTS}

This study was supported by the Ministry of Food and Drug Safety (MFDS) support project of the MFDS (Seoul, Korea), 2015.

\section{REFERENCES}

Braun, K., and D. T. Gibson. 1984. Anaerobic degradation of 2-aminobenzoate (anthranilic acid) by denitrifying bacteria. Appl. Environ. Microbiol. 48:102-107.

Evans, W. C. 1977. Biochemistry of the bacterial catabolism of aromatic compounds in anaerobic environments. Nature 270:17-22.

García, I., M. C. Ortiz, L. Sarabia, C. Vilches, and E. Gredilla. 2003. Advances in methodology for the validation of methods according to the International Organization for Standardization: Application to the determination of benzoic and sorbic acids in soft drinks by high-performance liquid chromatography. J. Chromatogr. A 992:11-27.

Garmiene, G., J. Salomskiene, I. Jasutiene, I. Macioniene, and I. Miliauskiene. 2010. Production of benzoic acid by lactic acid bacteria from Lactobacillus, Lactococcus and Streptococcus genera in milk. Milchwissenschaft 65:295-298.

Hegnauer, R. 1992. Benzoesaure. Chemotaxonomic der pflanzen. Basel, Birkhauser Verlag. 415-416.

Hejtmánková, A., V. Horák, J. Dolejšková, F. Louda, and H. Dragounova. 2000. Influence of yoghurt cultures on benzoic acid content of yoghurt. Czech. J. Food Sci. 18:52-54.

Horníčková, Š., H. Dragounová, K. Hejtmánková, T. Michlová, and A. Hejtmánková. 2014. Production of benzoic acid in fermented goat's and sheep's milk. Scientia Agriculturae Bohemica 45:247-253.

Iammarino, M., A. Di Taranto, C. Palermo, and M. Muscarella. 2011. Survey of benzoic acid in cheeses: Contribution to the estimation of an admissible maximum limit. Food Addit. Contam. Part B Surveill. 4:231-237. 
Kisza, J., W. Sajko, D. Sadowska, and K. Tyszkiewicz. 1984. Benzoic acid in dairy starters and cultured milk beverages. Zesz. Nauk. Akad. Roln. Techn. Olsztynie Technol. Zywnosci. 19:69-77.

Meyer, A. S., K. I. Suhr, P. Nielsen, and F. Holm. 2002. Natural food preservatives. Minimal processing technologies in the food industry. Pages 124-174 in Minimal Processing Technologies in the Food Industries. Woodhead Publishing, Cambridge, UK.

MFDS. 2014. Food Additives Codex. Ministry of Food and Drug Safety, Seoul, Korea.

Mroueh, M., D. Issa, J. Khawand, B. Haraty, A. Malek, Z. Kassaify, and I. Toufeili. 2008. Levels of benzoic and sorbic acid preservatives in commercially produced yoghurt in Lebanon. J. Food Agric. Environ. 6:62-66.

Nishimoto, T., M. Uyeta, and S. Taue. 1969. Precursor of benzoic acid in fermented milk. Shokuhin Eiseigaku Zasshi 10:410-413.

Ping, Q., H. Hong, X. Liang, and D. Liu. 2009. Assessment of benzoic acid levels in milk in China. Food Contr. 20:414-418.

Rukkwamsuk, T., K. Bumrungkit, and N. Thitichayaphong. 2012. Changes of lactic and benzoic acid concentrations in milk during post-collection period. J. Anim. Vet. Adv. 11:968-970.

Sajko, W., J. Kisza, and J. Niedziecki. 1984. Benzoic acid in raw cow milk. Zesz. Nauk. Akad. Roln. Techn. Olsztynie. Technol. Zywnosci 19:61-68.
Sieber, R., U. Bütikofer, and J. O. Bosset. 1995. Benzoic acid as a natural compound in cultured dairy products and cheese. Int. Dairy J. 5:227-246.

Tavaria, F. K., S. Dahl, F. J. Carballo, and F. X. Malcata. 2002 Amino acid catabolism and generation of volatiles by lactic acid bacteria. J. Dairy Sci. 85:2462-2470.

Toppino, P. M., R. Volpato, G. Amelotti, and G. Contarini. 1990. Determinazione quantitativa HPLC di acido sorbico e acido benzoico nei prodotti lattiero-caseari. Sci. Technol. Latt. Cas. 41:137-152.

Urbienè, S., and D. Leskauskaitè. 2006. Formation of some organic acids during fermentation of milk. Pol. J. Food Nutr. Sci. 15:277-281.

Yildiz, A., S. Erdogan, A. Saydut, and C. Hamamci. 2012. HighPerformance Liquid Chromatography analysis and assessment of benzoic acid in yogurt, ayran, and cheese in Turkey. Food Anal. Methods 5:591-595.

Ziegler, K., K. Braun, A. Bockler, and G. Fuchs. 1987. Studies on the anaerobic degradation of benzoic acid and 2-aminobenzoic acid by a denitrifying Pseudomonas strain. Arch. Microbiol. 149:62-69. 